\title{
Initial Offer Precision and M\&A Outcomes
}

\section{Citation}

Hukkanen, Petri, and Matti Keloharju. "Initial Offer Precision and M\&A Outcomes." Harvard Business School Working Paper, No. 16-058, November 2015.

\section{Permanent link}

http://nrs.harvard.edu/urn-3:HUL.InstRepos:23481356

\section{Terms of Use}

This article was downloaded from Harvard University's DASH repository, and is made available under the terms and conditions applicable to Other Posted Material, as set forth at http:// nrs.harvard.edu/urn-3:HUL.InstRepos:dash.current.terms-of-use\#LAA

\section{Share Your Story}

The Harvard community has made this article openly available.

Please share how this access benefits you. Submit a story.

Accessibility 


$$
\text { H A R VAR D B US INESS SCHOOL }
$$

\section{Initial Offer Precision and M\&A Outcomes}

Petri Hukkanen

Matti Keloharju

Working Paper 16-058 


\section{Initial Offer Precision and M\&A Outcomes}

Petri Hukkanen

Aalto University

Matti Keloharju

Harvard Business School

Working Paper 16-058 not be reproduced without permission of the copyright holder. Copies of working papers are available from the author. 


\title{
Initial Offer Precision and M\&A Outcomes*
}

\author{
Petri Hukkanen, Aalto University \\ Matti Keloharju, Aalto University, Harvard Business School, CEPR, and IFN
}

November 2, 2015

\begin{abstract}
Building on recent research in social psychology, this paper analyzes the link between the precision of initial cash offers and M\&A outcomes. About one-half of the offers are made at the precision of one or five dollars per share, and an additional one-third at the precision of half dollar or one quarter. The practice of making offers at round price-per-share levels is associated with the following unfavorable outcomes for the bidder: (1) higher purchase price for target shares, (2) lower probability to complete the deal, and (3) lower announcement return. A median-sized offer made at the precision of one or five dollars per share is associated with a 4-5 million dollars higher expected transaction price than one made at a precision greater than one quarter.
\end{abstract}

\footnotetext{
*Corresponding author: Matti Keloharju, email: mkeloharju@hbs.edu, matti.keloharju@aalto.fi. We are grateful to Leo Niemeläinen for superb research assistance, and to Malcolm Baker, Manuel Bagues, Harrison Hong, Juhani Linnainmaa, Matthijs Lof, Mikko Niemenmaa, Raghu Rau, Sami Torstila, Jeffrey Wurgler, and seminar participants at Aalto University, Goethe University, Karlsruhe Institute of Technology, the University of Strasbourg, and Wharton for their helpful comments. We thank the Marianne and Marcus Wallenberg Foundation for financial support.
} 


\section{Introduction}

In negotiations, first offers serve as anchors. A large literature in the area of social psychology finds counteroffers and the ultimate negotiation outcomes to be biased in the direction of the first offer, giving its maker a bargaining advantage. ${ }^{1}$ Experimental and field evidence from the real estate market suggest that the maker of the first offer may be able to further tilt the bargaining game to her advantage by expressing the offer price in precise terms. ${ }^{2}$ For example, a list price of $\$ 1,020,000$ is more informative and likely to lead to a smaller price adjustment than a list price of $\$ 1,000,000$. A precise list price hints that the seller has a precise estimate of the value of the real estate, and is unlikely to make significant concessions on the price.

Can precise initial offers tilt the bargaining game to the bidder's advantage also in M\&A deals? To our knowledge, this study is the first to test this idea. The mergers and acquisitions market is in many respects an ideal venue for testing the effect of precision on bidder outcomes. The market is very large, both in terms of the value and number of transactions, so the success of bidding strategies is of great economic importance. Moreover, the behavior of each party and deal outcomes are well documented and easily available to researchers from public databases. These data make it possible not only to assess the success of precise bids, but also to look for external validation for the merits of the precise-bid strategy by observing how the stock market responds to bids of various degrees of precision.

The market for corporate control gives rise to complex strategic behavior. ${ }^{3}$ In our setting, a bidder can hint at its confidence in the valuation of the target by expressing its bid more precisely. A bid for $\$ 10.20$ per share leaves the impression that the bidder is less likely to

\footnotetext{
${ }^{1}$ Chertkoff and Conley (1967), Yukl (1974), Galinsky and Mussweiler (2001), Gunia et al. (2013), and others show that the maker of the first offer has a bargaining advantage. Tversky and Kahneman (1974) are the first to document the anchoring effect. Apart from negotiation outcomes, anchoring has been shown to influence valuations (Northcraft and Neale, 1987; Ariely, Loewenstein, and Prelec, 2003), purchasing decisions (Wansink, Kent, and Hoch, 1998), and legal judgments (Englich and Mussweiler, 2001), among others. Baker, Pan, and Wurgler (2012) find that recent peaks in target share price serve as anchors in M\&A deals.

2 Janiszewski and $\mathrm{Yu}$ (2008) are the first to present this hypothesis and find consistent evidence using experimental and field data from the real estate market. Their results have been replicated in various experimental settings by Mason et al. (2013), Zhang (2013), Zhang and Schwarz (2013), and Lotchelder, Stuppi, and Trötschel (2014), among others. Thomas, Simon and Kadiyali (2010) find evidence in support of the hypothesis in the real estate market. In the finance literature, Harris (1991) suggests that traders use discrete prices to lower the costs of negotiating. The frequency of rounded prices is an increasing function of stock price and uncertainty concerning valuation. Bradley et al. (2004) and Mola and Loughran (2004) find that initial public offerings and seasoned equity offerings priced at rounded numbers generate higher initial returns.

${ }^{3}$ For a review of the literature, see e.g. Dasgupta and Hansen (2007) and Eckbo (2009).
} 
revise the bid significantly upward than a bid for $\$ 10.00$ per share. However, the target does not know the true motivations behind the precision of the bid: a bidder can place a precise bid because it genuinely has a narrow valuation range, or to bluff the target into accepting a lower price. Whether bidders express their bids in precise terms and whether precise bids lead to better outcomes such as less price adjustment, are open empirical questions. Apart from being interesting in their own right, addressing these questions informs us of the nature of the bargaining game played by the bidder and the target.

We start our analysis by documenting the precision of initial offers. Fourteen percent of initial cash bids are expressed at the precision of five dollars per share, and about one half at the precision of one dollar. Only one-sixth of the offers are expressed at a precision greater than one quarter. Given that most bidders place their bids at a relatively coarse level, placing a precise bid to bluff the target cannot be common.

We next test our main hypothesis: that offers with more precise initial prices are associated with a smaller price change. The evidence is consistent with the hypothesis. For example, making an offer at the precision of five dollars (one dollar) is associated with a $10 \%(8 \%)$ higher price change than placing an offer at a precision greater than one quarter. These results are significant at the $1 \%$ level and suggest that coarse offers magnify the change in the final deal price. For the median (mean) transaction, a bid made at the precision of one or five dollars is associated with a 4-5 (14-18) million dollars higher expected transaction price than one made at a precision greater than one quarter.

We also test the hypothesis that precise offers increase the likelihood that the initial bidder is able to close a deal with the target. There are at least two reasons why this could be the case. First, competing bidders may view precise offers as more informed, and, perhaps because of the winner's curse, may not wish to enter a bidding contest against an ostensibly more informed bidder (Fishman, 1988; Povel and Singh, 2006). Second, targets may interpret precise offers as evidence that the acquirer is informed and knows what it is doing. Given the many challenges associated with post-merger integration (see, for example, Shrivastava, 1986 and Epstein, 2004), targets may be more willing to close the deal with a party they consider competent. Our results are consistent with the hypothesis: an initial offer placed at a precision greater than one quarter is $8 \%(6 \%)$ more likely to lead to a deal than an offer placed at the precision of five dollars (one dollar). These results are significant at the $1 \%(5 \%)$ level. 
Cash bids tend to generate positive market reactions for the acquirer and precise bids tend to be associated with a higher success rate and more favorable deal terms. Does the market consequently view an acquirer's precise bid more positively than a round one? Our results suggest that it does. A bid placed at a precision greater than one quarter is associated with 2.0 (2.0) percentage points higher market reaction than a bid placed at the precision of five dollars (one dollar). These results, which are significant at the $10 \%$ level, give external validation to the argument that offer precision matters for bidders.

Are the favorable outcomes associated with precise bids outweighed by other, unfavorable outcomes? We examine three alternative outcomes but find no support for this conjecture. More specifically, precise bids are not associated with a greater likelihood of price change, or competing offers, nor does it take a longer time to close a deal initiated by a precise bid; if anything, our evidence suggests the opposite. For example, bids made at a precision greater than one quarter have a significantly shorter duration than those made at the precision of five dollars.

The monetary cost of making a precise offer is very small: the bidder can change a round offer price to a non-round one by adding or subtracting a few cents per share. To give a conservative example, a 10-cent increase in offer price would add 1.3 million dollars to the cost of the median offer; this is less than one third of the 4-5 million dollars expected cost in adjustment implied by our regression estimates. ${ }^{4}$ Non-rounding would naturally be necessary only in the rare case where the bidder's valuation recommends a round offer price. On an expected basis, the cost-benefit ratio of non-rounding would thus be considerably better than one-third.

If round offers generate worse outcomes, why do almost five-sixths of the bidders make them? We think this is because people are hardwired to do so: round numbers are cognitively least costly. A sizeable literature suggests that people often write and speak about round numbers rather than precise numbers (e.g. Baird et al., 1970; Dehaene and Mehler, 1992; and Jansen and Pollman, 2001). Compared to coarse expressions (e.g., one year), fine-grained expressions (e.g., 12 months) are more likely to be used when communicators have confidence in what they say (Channel, 1994; Yaniv and Foster, 1995; Goldsmith, Koriat, and

\footnotetext{
${ }^{4}$ Note that the change in the offer price could also be negative, which would lower the cost of the offer. Moreover, the change in the price may be smaller than 10 cents per share.
} 
Weinberg-Eliezer, 2002; Welsh, Navarro, and Begg, 2011). Mason et al. (2013) find that these tacit norms also apply to negotiations, including those involving sophisticated parties. In a negotiation experiment, they document that experienced executives and MBA students tend to make round initial offers if not told otherwise. The preference for round numbers shows up even in high-stake games played by sophisticated parties. Using data from individual polling stations from Russia's parliamentary elections in 2011 (presidential elections in 2012), Kobak et al. (2012) show that the share of votes for the ruling United Russia party (Vladimir Putin) displayed sharp peaks at the round numbers of $65 \%, 70 \%, 75 \%$ etc. The supernatural character of the peaks strongly suggests that the votes for the winners were manipulated a posteriori to fix the vote shares at appealing round values. Klimek et al. (2012) study election results around the world and show that many elections leave statistical fingerprints of fraud that can be uncovered using elementary statistical methods.

Why do targets respond differently to round and precise offers? In cooperative discussions, a recipient generally assumes that the given information is as informative as required, but not more than that (Grice, 1975). Therefore, the recipient is inclined to infer from a precise offer that all digits are required to express the value of the target. Recipients also consider precise offers more informed and are more likely to rely on what they convey (Zhang and Schwarz, 2012; Schley and Peters, 2013). Recipients can detect others' confidence based on the precision, which influences their judgments and preferences for seeking advice (JerezFernandez, Angulo, and Oppenheimer, 2014).

Both acquirers and targets are advised by investment banks which have lots of experience on merger negotiations. Why don't investment banks recommend all of their acquirer-clients to make precise bids? And why don't the advisors of targets see through and discount the gaming aspect of precise bids? It appears that many bankers are simply unaware of the gaming aspect associated with precise offers and go with the market practice, i.e. the cognitively least costly option. The first research on the effect of precise offers on negotiation outcomes was published in 2008, and it is safe to assume that the results of this research are not yet well known outside a few fields in the academia, let alone among acquirers, targets, and their advisors. To assess whether bankers intuitively understand the strategic implications of the precision of the initial offer price, we conducted semi-structured interviews with ten current or former investment bankers with on average 14 years of experience on M\&A deals. When asked whether they as the advisor of the bidder would tend to recommend a round or a 
precise bid price, only one of them expressed a clear preference for precise prices. This banker had the same story as us in his mind. Two bankers expressed a weak preference for precise bids, but they could not properly explain why. The remaining seven bankers either did not express a preference for precise or round bids, or preferred round bids because of the prevailing market practice. All in all, the bankers' responses are in agreement with the observation that precise bids are relatively uncommon.

It is also useful to note that target bankers often have an incentive to advise their clients to accept an offer. In the average contract, over $80 \%$ of the fee is paid only if the acquisition is completed (McLaughlin, 1990); advising the client to decline the initial bid would jeopardize this fee. Given that there is no uncertainty in the valuation of a cash offer, and that about two thirds of all initial offers are accepted as such, the reputational risk of advising a client to accept the offer is probably small. The target's bank writes in about $80 \%$ of the deals a fairness opinion on the offer price (Kisgen, Qian, and Song, 2009), but the uncertainties related to the valuation task should make it easy to write an opinion that is consistent with the initial offer price being fair to target shareholders. Cain and Denis (2013) document that in target-side fairness opinions the high minus low valuation range is on average $60 \%$ of the offer price. Both the mean and the median valuations are below the offer price.

Admittedly, no regression methodology involving bidding behavior in mergers and acquisitions can completely mimic an experiment with true randomization of treatments; one cannot randomly shock the bidders to assign differing bid strategies, nor can a researcher develop perfect instruments for bid precision that are not subject to some endogeneity biases. What makes us then think that the relationship we uncover is about bid precision and not some other attribute (say, private communication between the bidder and the target prior to the public initial bid) that happens to be correlated with precision?

First, we have minimized the effect of omitted variables by including in our regressions all the usual suspects that might account for our findings; any remaining variables are likely to be unobservable not only to us but also to potential rival bidders and to investors at large. Omitted variables such as potential private pre-offer communications between the acquirer and the target would thus have a hard time explaining why the announcement reaction is more positive for precise than for round bids. To avoid peeking into the future, our tests only include controls that are known at the time of the initial offer. 
Second, offer precision is a choice variable that can be mimicked without any and at worst with a relatively small monetary cost (and perhaps with a marginally larger cognitive cost). Here, the fact that precise offers are rare works in our favor, as there are plenty of untapped opportunities for making precise offers. To the extent that more precise offers are associated with better outcomes, rational bidders (that are aware of the benefits of precision) would be expected to make precise offers regardless of whether any of the variables potentially omitted from our regressions recommend a round or precise offer price.

While we think that our parameter estimates represent a fair characterization of the effects of precision on offer outcomes for the marginal bidder, we do not claim that they can be causally interpreted in the whole bidder population. Most initial bids have historically been, and continue to be, relatively coarse. If all bidders switched to making precise bids, the information content of precision would decrease to zero. But as long as they do not, and the targets do not fully internalize the ramifications of the bidders' bluff, bidders can expect to benefit from making precise bids.

\section{Data and empirical results}

A. Sample restrictions and key variable definitions

We collect all cash offers made on publicly listed US-based targets and announced between January 1, 1985 and December 31, 2012 from Securities Data Corporation's (SDC) mergers and acquisition database. ${ }^{5}$ To be included in the sample, the bidder must be based in the US and the proposal must be an initial offer to obtain a majority interest of a target listed on the New York Stock Exchange (NYSE), NASDAQ, or American Stock Exchange (AMEX). The bidder does not need to be publicly listed. Offers for which either the CRSP or the Compustat data is missing are excluded from the sample. To ensure sufficient homogeneity in the precision of the bid prices, we require the initial offer to be at least five dollars per share. ${ }^{6}$ Furthermore, we require that the offer is not classified by SDC as a repurchase, recapitalization, restructuring, or joint venture. Finally, we drop four observations which have either apparent data errors or where the offer outcome has been agreed upon before

\footnotetext{
${ }^{5}$ We restrict our analysis to the precision of pure cash bids because the SDC data does not indicate whether the exchange ratio in a stock offer applies to the initial or a later bid. Cash bids also do not require bidder shareholder approval, giving the bidder management more discretion in formulating the bids.

${ }^{6}$ See, for example, Bradley et al. (2004).
} 
announcing the initial bid. In these observations SDC reports that the deal was closed on the same day the initial bid was announced.

SDC reports two key price per share items, the initial price per share and the (final) price per share. We focus on the initial bid price (and not on potential intermediate bids) because of its unique anchoring role and its strong predictive power on negotiation outcomes in the social psychology literature. ${ }^{7}$ We define the change in bid price as the relative difference between these two price items. The variable is defined only if one of the bids in the takeover contest is completed.

We define takeover contests as in Betton et al. (2008). First, we define as control offers bids which SDC classifies as Acquisitions of majority interests (deal form AM) or as mergers (M) and where the bidder starts with less than $50 \%$ of the target firm shares outstanding. Second, each individual target is identified based on a CUSIP number. A takeover contest is started when the first control offer is made for a given target and continues until 126 trading days have passed without any subsequent offer. Each time an additional offer for the target is identified, the 126-trading day search window rolls forward.

We also follow Betton et al. (2008) in the computation of the duration of the takeover contest. For successful offers, duration is defined as the number of calendar days between the announcement of the initial offer and the completion date of the deal. For unsuccessful offers, duration is defined as the difference in calendar days between the initial offer date and the date of the last offer announcement, plus 126 days. Following Jaggia and Thosar (1995), we right censor duration at 365 days. This censoring applies to 31 observations, i.e. less than $2 \%$ of the sample.

We study market reactions to initial bids by calculating three-day cumulative abnormal returns around each event. Abnormal returns are computed as returns in excess of those predicted by the market model; following Bradley, Desai, and Kim (1988), we estimate the market model parameters using daily data from event days $[-300,-61]$. To assure that each event is important enough for the acquirer to be able to trigger a market reaction, we require

\footnotetext{
${ }^{7}$ In addition, the number of initial bids is much larger than the number of subsequent bids. Even if subsequent bids would be expected to be associated with M\&A outcomes, the relation would likely to be too noisy to detect because of the small number of observations.
} 
that the total transaction value accounts for at least ten percent of the acquirer's equity market value. $^{8}$

\section{B. Descriptive statistics}

Figure 1 investigates the degree to which the initial bids are clustered at round numbers. Panel A shows clear patterns in the initial bids: almost one-half of them are placed at the precision of one dollar, $19 \%$ at the precision of half dollar, and $15 \%$ at the precision of one quarter. Only $18 \%$ of the bids are expressed at a precision greater than one quarter. In other words, bidders rarely place precise bids, neither in the absolute sense nor when compared with closing prices. ${ }^{9}$ If precise bids give a bargaining advantage, most bidders must be unaware of it.

Panel B studies the bids made at the precision of one dollar in more detail. It shows that bids whose last digit is 5 and 0 , i.e. bids made at the precision of five dollars, are somewhat more common than other bids. Combined these bids account for $14 \%$ of all bids.

Table 1 reports means, standard deviations, medians and extreme values for the precision, contest outcome, and control variables. The initial bidder wins the deal in about three-fourths of all bids. Ten percent of all bids are contested, and the median contest duration is 113 calendar days. The bid price changes from the initial bid in $18 \%$ of the cases; the average price change (conditional on a non-zero price change) is $14 \%$. The price change is usually positive, but findings from the due diligence process sometimes cause the price to be revised downward. The average three-day announcement return for the acquirer is $1.3 \%$.

Table 2 reports univariate statistics on the relationship between bid precision and offer outcomes. The relationship between bid precision and offer success is almost monotonic. The initial bidder wins $69 \%$ of the bids made at the precision of five dollars, whereas in the other end, at a precision greater than one quarter, the initial bidder wins $84 \%$ of the time. The

\footnotetext{
${ }^{8}$ See, for example, Officer, Poulsen, and Stegemoller (2009).

${ }^{9}$ For example, Harris (1991) documents that $16 \%(14 \%)$ of closing prices take place at the precision of one dollar (half dollar). Using a post-decimalization sample, Ikenberry and Weston (2008) find that 4.6\% (3.4\%) of the closing prices take place at the precision of one dollar (half dollar). Although not reported formally, the precision distribution of initial bid prices is quite similar both before and after the decimalization in 2001. For example, offers with precision greater than one quarter accounted for $15.4 \%$ of the bids in the pre-decimalization period and $19.9 \%$ in the post-decimalization period.
} 
difference between these two numbers is significant at the $1 \%$ level $(z$-value $=-4.32)$ and suggests that precise bids tend to be more successful.

Table 2 also suggests that greater bid precision is associated with a smaller price change from the initial bid price to final price. The relationship between bid precision and average price change is almost monotonic. Conditional on a price change, bids made at the precision of five dollars generate on average a price change of $17.6 \%$, whereas the corresponding price change for bids made at a precision greater than one quarter is $6.0 \%$. The difference between these numbers is significant at the $1 \%$ level $(t$-value $=3.43)$. These results are consistent with the idea that targets anchor more on precise initial offers than on round offers.

Finally, Table 2 reports the association between bid precision and the three-day announcement return for the acquirer. The most rounded bids, i.e. those made at the precision of five dollars or one dollar, are associated with announcement returns of $0.1 \%$ and $0.2 \%$, respectively. Bids made at a greater precision generate 2-3 percentage points higher announcement returns, a difference that is significant at the $10 \%$ level. These results are consistent with the idea that the marginal trader in the stock market thinks that precise bids are better for acquirers than round bids.

\section{Multivariate results}

\section{C.1. Likelihood of making a successful bid}

Table 3 reports the results from logit regressions which relate the likelihood to make a successful bid to initial bid precision and controls. Specification 1 reports the association between the bid precision variables and offer success. Consistent with Table 2, all precision variables are significantly negative at the 5\% level, suggesting that placing a bid at a precision greater than one quarter (the omitted variable) is associated with a greater chance for the initial bidder to be successful than a bid placed at a lower precision.

Specification 2 drops the bid precision variables and instead adds control variables to the regression equation. All controls are known at the time of the first bid; therefore, for example, we do not include information on rival bidders. The controls include tender offers (e.g. Betton et al, 2009), hostile offers (Schwert, 2000), the inverse of offer price (Baker et. al., 2012), horizontal offers (Betton et al, 2009), premium (Betton and Eckbo, 2000), toehold (Betton and 
Eckbo, 2000), and public acquirers (Betton et al, 2009). In addition, in the spirit of Moeller et al. (2004) and Baker et al. (2012), we control for the size of the transaction. Our results suggest that public acquirers, tender offers, horizontal offers, offers made at higher prices, and large offers tend to be associated with a significantly greater chance of success, whereas hostile offers tend to be associated with a significantly smaller chance of success.

Specification 3 includes both the precision variables and controls in the regression equation. All the precision variables survive the addition of controls and remain significantly negative at least at the 5\% level. For example, placing a bid at the precision of five dollars has a marginal effect of $0.079(t$-value $=-2.60)$, i.e. it is associated with a $8 \%$ lower likelihood for the initial bidder to win a deal than a bid made at the precision greater than one quarter. The corresponding marginal effect for an initial bid made at the precision of one dollar is 0.057 ( $t$ value $=-2.01)$. These results are consistent with the idea that targets prefer precise offers.

\section{C.2. Relative price change}

Table 4 runs a series of OLS regressions that associate relative price change from the initial bid to final price for all successful bids. While the structure of the table is the same as in Table 3, the sample is much smaller because we limit our analysis to events where the final price differs from the initial bid price. Specification 1 regresses the price change against the bid precision variables. Consistent with Table 2, the three coarsest bid precision variables are all associated with significantly greater price change than bids made at a precision greater than one quarter.

Specification 2 reports the results for the same battery of control variables as in Table 3 , except that it also adds the target's return volatility to account for the degree of uncertainty in the valuation of the target. Among the control variables, only one variable, the hostile offer dummy, is significantly related to the price change.

Specification 3 includes both the bid precision variables and control variables in the regression. Among the bid precision variables, all but the one quarter dummy are associated with statistically significantly higher bid price changes than bids made at a precision greater than one quarter. The results are also economically highly significant. For example, making a bid at the precision of five (one) dollars is associated with a $10.1 \%(7.6 \%)$ greater price change than those made at a precision greater than one quarter. Assessed at the median 
(mean) transaction value of 254 (986) million, and taking into account the unconditional probability for a price change of $18.2 \%$, these two coefficient estimates translate into coarse bidders paying 4.7 (18.1) and 3.5 (13.6) million dollars more for their targets, respectively. Note that these calculations ignore any association between the bid precision variables and the probability of price change. Subsection C.4 documents that if anything, precise offers are associated with a smaller likelihood of price change. Thus, our estimates on the benefits of precise offers err on the side of caution.

\section{C.3. Acquirer announcement effect}

Table 5 studies the announcement effect of an initial bid for the acquirer. This analysis is motivated by three separate findings. First, Table 3 indicates that precise initial bids are associated with a higher likelihood of offer success than round ones. Second, Table 1 suggests that initial bids tend to generate a positive announcement effect, so a strategy increasing the chances of a successful offer is expected to benefit the acquirers' shareholders. Third and finally, Table 4 finds precise offers to be associated with a smaller price change from the initial bid price. Combined, these three results lead us to hypothesize that an acquirer's precise initial bid is greeted with a more positive market response than a round one. ${ }^{10}$

Table 5 is structured in the same way as Table 3 and Table 4 . The sample is considerably smaller than in Table 3 because only about one-half of all bidders are listed and because we require the transaction to account for at least $10 \%$ of the size of the bidder. Specification 1 regresses the three-day cumulative market-adjusted return against the bid precision variables. Consistent with Table 2, the two coarsest bid precision variables are associated with a greater announcement return than bids made at a precision greater than one quarter.

Specification 2 reports the results for the battery of control variables used in Table 3, along with the relative size of the transaction (e.g. Chang, 1998, and Fuller, Netter, and Stegemoller, 2002). The results suggest that offers where the transaction is large relative to the acquirer are associated with significantly larger market reactions, whereas hostile offers and large offers are associated with significantly smaller market reactions.

\footnotetext{
${ }^{10}$ Note that a similar hypothesis cannot be drawn from the target's market reaction. While the target is expected to benefit from an increase in the likelihood to complete an offer, it is expected to lose from a decrease in the price paid for its shares. Consistent with these two conflicting forces offsetting one another, Table IA1 in Internet Appendix finds no significant relation between initial bid precision and target event reaction in the specification controlling for other bid attributes.
} 
Specification 3 includes both the bid precision and control variables in the regression. Making a bid at the precision of five dollars (one dollar) is associated with a 2.0 (2.0) percentage points lower market reaction than making one at a precision greater than one quarter. Despite the inevitable noise driven by the small sample, these results are statistically significant at the $10 \%$ level. Overall, our results are consistent with the idea that the market interprets precise bids more positively than round ones.

\section{C.4. Alternative outcomes}

Our tests suggest that precise bids are associated with a number of positive outcomes for the bidder. In this subsection we test whether these favorable outcomes are outweighed by other, potentially unfavorable outcomes. We examine the following three outcomes: the likelihood of competing offers, the likelihood of a price change, and contest duration.

Table IA2 in Internet Appendix studies whether bid precision is associated with the likelihood of competing offers. Specification 1 finds that bids placed at the precision of five dollars or half dollar are significantly more likely to generate competing bids than bids presented at a precision greater than one quarter ( $t$-values: 1.82 and 2.47, respectively). These results are consistent with the idea that precise offers appear more informed and discourage rivals to enter a bidding contest against an ostensibly more informed bidder (Fishman, 1988, and Povel and Singh, 2006). The bid precision variables lose their significance in Specification 3 which controls for other bid attributes. None of the specifications suggest that more precise bids would be associated with a greater degree of competition.

We also consider the possibility that the likelihood of a price change could be a function of bid precision. To test this conjecture, Table IA3 regresses the likelihood of a price change on the bid precision variables and controls. Specification 1 shows that bids made at the precision of five dollars and one dollar are significantly or almost significantly more likely to be associated with price change than bids made at the precision greater than one quarter ( $t$ values: 1.55 and 1.89 , respectively). Specification 3 adds controls for bid attributes to the regression, which make the bid precision variables lose their significance. None of the specifications suggest that more precise bids would be associated with a greater probability of price change. 
Finally, we test whether offer precision is associated with the duration of the bidding contest. Specification 1 in Table IA4 finds that bids made at a precision greater than one quarter have a significantly shorter contest duration than those made at the precision of five dollars ( $t$-value $=-3.78)$, or one dollar $(t$-value $=-2.38)$. The five-dollar coefficient remains significant at the $10 \%$ level $(t$-value $=-1.87)$ even when other bid attributes are controlled for. These results indicate that it does not take a longer time to close a deal initiated by a precise bid; if anything, our evidence suggests the opposite. All in all, none of the alternative outcomes analyzed in this subsection speaks against idea that round bids are associated with unfavorable acquirer outcomes.

\section{C.5. Robustness checks}

We perform two additional batteries of robustness checks whose results we omit for brevity. First, we check whether the association between bid precision and offer outcomes changes if we control for the quality of the advice of the bidder's investment bank. Following Gobulov, Petmezas, and Travlos (2012), we measure advice quality with a dummy for whether the advisor is one of the top- 8 investment banks. The information on the investment bank is available only for about two-thirds of the deals, so we add a separate dummy for deals for which the quality of the advisor is not known. Adding these two dummies to our tests leaves the results qualitatively unchanged.

Second, we consider the possibility that price precision could mean different things for small and large price per share offers. Although our tests already omit all offers below $\$ 5$ per share and control for the inverse of offer price, as an extra precaution we homogenize the sample further by throwing out all offers for at least $\$ 30$ per share, or about one-fourth of the sample. This change has no discernible effect on the association between bid precision and offer outcomes.

D. Evidence from semi-structured interviews

Do bankers and corporate professionals responsible for M\&A deals intuitively understand the strategic implications of the precision of the initial offer price? We explore this by contacting ten senior M\&A professionals for a semi-structured interview. All of them agreed to be interviewed. Four of them work and two have worked as an investment banker in a bulgebracket bank. The remaining four individuals draw their investment banking experience from 
Finland. Apart from their investment banking experience, two of the interviewees have experience from senior corporate roles in M\&A transactions, and one from a senior role in private equity. Table 6 Panel A reports descriptive statistics on the interviewees. Table 6 Panel B reports descriptive statistics on their experience (on average 14 years) and the length of the interview (on average 23 minutes).

We asked the respondents to assume that they serve as the advisor of an acquirer and that they have done all the preparatory steps needed to make the initial offer of a public target. The respondents were asked to assume that the offer is a cash-only offer and assume away any elements that would complicate the deal. They were then asked to compare two hypothetical initial cash offers, one made at $\$ 15.00$ per share (referred to later as "round" bid) and another made at $\$ 15.20$ per share (referred to later as "precise" bid). The interviewees were asked to ignore the price difference between these two options; those interviewees who felt that the offer price difference was important were asked for symmetry to assume a third bid price option, $\$ 14.80$ per share. The interviewees were also asked how strongly they felt about their choice.

Only one of the interviewees strongly preferred the precise bid option. His argument was the same as ours: a round bid signals that the bidder does not have a good idea of the appropriate price and that the price is subject to negotiation. Two of the interviewees weakly preferred the precise option. Neither of them could properly explain why without being helped by the interviewer. When a third option of $\$ 14.80$ per share was introduced, one of these respondents came up with the same argument as we have in our paper. He added that he had not thought of this argument before the interview. Two interviewees did not prefer either option. Five interviewees preferred a round bid because it reflects the market convention. Two of them had a strong preference for a round price. Panel C reports the distribution of the respondents' preference for round vs. precise bids.

We also asked whether the interviewees remember having discussed bid precision with their colleagues. Three of them did; of these interviewees, two preferred precise bids and one preferred round bids. None of the interviewees were aware of the academic literature on the effect of rounding on negotiation outcomes. Table 6 Panel D summarizes the other responses of the interviewees. 
To sum up, our results cast doubt on the idea that corporate acquirers and their advisors would generally be knowledgeable of the effect initial offer precision has on acquisition outcomes. The absence of insight of a better option makes it natural for advisors to recommend, and acquirers to follow, the market convention of placing a round offer.

\section{Conclusion}

Building on recent research in the area of social psychology, this paper analyzes the link between the precision of initial offers and M\&A outcomes. We start our analysis by documenting that the initial offer price per share is usually expressed at coarse terms. We then show that this widely spread practice is associated with three kinds of unfavorable outcomes for the bidder. First, a round initial offer price is associated with a higher price paid for the target shares. Second, it is associated with a lower probability for the initial bidder completing the deal. Third, the stock market response for an offer expressed at coarse terms is less positive than for one expressed at precise terms.

Our results have applications for M\&A practice. First, some bidders may use round offer prices on purpose to make the target feel like the bidder left some "meat on the bone" for them, hoping this will improve their chances of winning the deal. Our results speak against this idea: round offer prices are not only associated with a higher price adjustment, but also with a lower chance for the initial bidder winning the deal. Second, it is virtually costless to change the offer price from a round number to a precise one, allowing the bidder to signal (or hide) its private information (or lack of it) on the accuracy of its valuation of the target. If the link between bid precision and M\&A outcomes remains as strong in the future as it has been until now, this simple intervention can increase the chances of a successful offer and yet generate significant cost savings.

We expect our results to inspire researchers to study the effect of precision on other outcomes in financial markets. For example, one can test whether analyst estimates expressed at precise terms are more influential and associated with more herding than ones expressed at coarse terms. Testing this hypothesis is left for future work. 


\section{References}

Ariely, Dan, George Loewenstein, and Drazen Prelec, 2003, "Coherent arbitrariness": Stable demand curves without stable preferences, Quarterly Journal of Economics 118(1), 73-105.

Baird, John C., Charles Lewis, and Daniel Romer, 1970, Relative frequencies of numerical responses in ratio estimation, Perception \& Psychophysics 8(5), 358-362.

Baker, Malcolm, Xin Pan, and Jeffrey Wurgler, 2012, The effect of reference point prices on mergers and acquisitions, Journal of Financial Economics 106(1), 49-71.

Betton, Sandra, and B. Espen Eckbo, 2000, Toeholds, bid jumps, and expected payoffs in takeovers, Review of Financial Studies 13(4), 841-882.

Betton, Sandra, B. Espen Eckbo, and Karin Thorburn, 2008, Corporate takeovers, in: Handbook of Corporate Finance: Empirical Corporate Finance, Volume 2 (B. Espen Eckbo, Ed.), Elsevier.

Betton, Sandra, B. Espen Eckbo, and Karin Thorburn, 2009, Merger negotiations and the toehold puzzle, Journal of Financial Economics 91(2), 158-178.

Bradley, Daniel J., John W. Cooney, Bradford D. Jordan, and Ajai K. Singh, 2004, Negotiation and the IPO offer price: A comparison of integer vs. non-integer IPOs, Journal of Financial and Quantitative Analysis 39(3), 517-540.

Bradley, Michael, Anand Desai, and E Han Kin, 1988, Synergistic gains from corporate acquisitions and their division between the stockholders of target and acquiring firms, Journal of Financial Economics 21(1), 3-40.

Cain, Matthew and David Denis, 2013, Information production by investment banks: Evidence from fairness opinions, Journal of Law and Economics 56(1), 245-280.

Chang, Saeyoung, 1998, Takeovers of privately held targets, methods of payment, and bidder returns, Journal of Finance 53(2), 773-784.

Channell, Joanna, 1994, Vague language, Oxford University Press. 
Chertkoff, Jerome M., and Melinda Conley, 1967, Opening offer and frequency of concession as bargaining strategies, Journal of Personality and Social Psychology 7(2), 181-185.

Dasgupta, Sudipto, and Robert G. Hansen, 2007, Auctions in corporate finance, in: Handbook of Corporate Finance: Empirical Corporate Finance, Volume 1 (B. Espen Eckbo, Ed.), Elsevier.

Dehaene, Stanislas, and Jacques Mehler, 1992, Cross-linguistic regularities in the frequency of number words, Cognition 43(1), 1-29.

Eckbo, B. Espen, 2009, Bidding strategies and takeover premiums: A review, Journal of Corporate Finance 15(1), 149-178.

Englich, Birke, and Thomas Mussweiler, 2001, Sentencing under uncertainty: Anchoring effects in the courtroom, Journal of Applied Social Psychology 31(7), 1535-1551.

Epstein, Marc, 2004, The drivers of success in post-merger integration, Organizational Dynamics 33(2), 174-189.

Fishman, Michael, 1988, A theory of preemptive takeover bidding, Rand Journal of Economics 19(1), 88-101.

Fuller, Kathleen, Jeffry Netter, and Mike Stegemoller, 2002, What do returns to acquiring firms tell us? Evidence from firms that make many acquisitions, Journal of Finance 57(4), $1763-1793$.

Galinsky, Adam D., and Thomas Mussweiler, 2001, First offers as anchors: the role of perspective-taking and negotiator focus, Journal of Personality and Social Psychology 81(4), 657-669.

Goldsmith, Morris, Asher Koriat, and Amit Weinberg-Eliezer, 2002, Strategic regulation of grain size memory reporting, Journal of Experimental Psychology: General 131(1), 73-95.

Golubov, Andrey, Dimitris Petmezas, and Nickolaos G. Travlos, 2012, When it pays to pay your investment banker: New evidence on the role of financial advisors in M\&As, Journal of Finance 67(1), 271-311. 
Grice, H. Paul, 1975, Logic and conversation, in: Syntax and Semantics, Volume 3 (Ed. Peter Cole and Jerry Morgan), Academic Press.

Gunia, Brian C., Roderick I. Swaab, Niro Sivanathan, and Adam D. Galinsky, 2013, The remarkable robustness of the first-offer effect across culture, power, and issues, Personality and Social Psychology Bulletin 39(12), 1547-1558.

Harris, Lawrence, 1991, Stock price clustering and discreteness, Review of Financial Studies 4(3), 389-415.

Ikenberry, David L., and James P. Weston, 2008, Clustering in US stock prices after decimalisation, European Financial Management 14(1), 30-54.

Jaggia, Sanjiv, and Satish Thosar, 1995, Contested tender offers: An estimate of the hazard function, Journal of Business \& Economic Statistics 13(1), 113-119.

Janiszewski, Chris, and Dan Uy, 2008, Precision of the anchor influences the amount of adjustment, Psychological Science 19(2), 121-127.

Jansen, Carel, and Mathijs Pollmann, 2001, On round numbers: Pragmatic aspects of numerical expressions, Journal of Quantitative Linguistics 8(3), 187-201.

Jerez-Fernandez, Alexandra, Ashley N. Angulo, and Daniel M. Oppenheimer, 2014, Show me the numbers: Precision as a cue to others' confidence, Psychological Science 25(2), 633-635.

Kisgen, Darren, Jung Qian, and Weihong Song, 2009, Are fairness opinions fair? The case of mergers and acquisitions, Journal of Financial Economics 91(2), 179-207.

Klimek, Peter, Yuri Yegorov, Rudolf Hanel, and Stefan Thurner, 2012, Statistical detection of systematic election irregularities, Proceedings of the National Academy of Sciences 109(41), 16469-16473.

Kobak, Dmitry, Sergey Shpilkin, and Maxim Pshenichnikov, 2012, Statistical anomalies in 2011-2012 Russian elections revealed by 2D correlation analysis, Imperial College working paper. 
Loschelder, David D., Johannes Stuppi, and Roman Trötschel, 2014, “€14,875?!”: Precision boosts the anchoring potency of first offers, Social Psychological and Personality Science 5(4), 491-499.

Mason, Malia F., Alice J. Lee, Elizabeth A. Wiley, and Daniel R. Ames, 2013, Precise offers are potent anchors: Conciliatory counteroffers and attributions of knowledge in negotiations, Journal of Experimental Social Psychology 49(4), 759-763.

McLaughlin, Robyn, 1990, Investment-banking contracts in tender offers: An empirical analysis, Journal of Financial Economics 28(1), 209-232.

Moeller, Sara, Frederik Schlingemann, and René Stulz, 2004, Firm size and the gains from acquisitions, Journal of Financial Economics 73(2), 201-228.

Mola, Simona, and Tim Loughran, 2004, Discounting and clustering in seasoned equity offering prices, Journal of Financial and Quantitative Analysis 39(1), 1-24.

Northcraft, Gregory, and Margaret Neale, 1987, Experts, amateurs, and real estate: An anchoring-and-adjustment perspective on property pricing decisions, Organizational Behavior and Human Decision Processes 39(1), 84-97.

Officer, Micah S., Annette B. Poulsen, and Mike Stegemoller, 2009, Target-firm information asymmetry and acquirer returns, Review of Finance 13(3), 467-493.

Povel, Paul, and Rajdeep Singh, 2006, Takeover contests with asymmetric bidders, Review of Financial Studies 19(4), 1399-1431

Schley, Dan, and Ellen Peters, 2013, Precise numbers are more believable, Ohio State University working paper.

Schwert, G. William, 2000, Hostility in takeovers: in the eyes of the beholder? Journal of Finance 55(6), 2599-2640.

Shrivastava, Paul, 1986, Postmerger integration, Journal of Business Strategy 7(1), 65-76.

Thomas, Manoj, Daniel H. Simon, and Vrinda Kadiyali, 2010, The price precision effect: Evidence from laboratory and market data, Marketing Science 29(1), 175-190. 
Tversky, Amos, and Daniel Kahneman, 1974, Judgment under uncertainty: Heuristics and biases, Science 185(4157), 1124-1131.

Wansink, Brian, Robert J. Kent, and Stephen J. Hoch, 1998, An anchoring and adjustment model of purchase quantity decisions, Journal of Marketing Research 35(1), 71-81.

Welsh, Matthew B., Daniel J. Navarro, and Stephen H. Begg, 2011, Number preference, precision and implicity confidence, Proceedings of the 33rd Annual Meeting of the Cognitive Science Society, 1521-1526.

Yaniv, Ilan, and Dean Foster, 1995, Graininess of judgment under uncertainty: An accuracyinformativeness trade-off, Journal of Experimental Psychology: General 124(4), 424-432.

Yukl, Gary, 1974, Effects of the opponent's initial offer, concession magnitude and concession frequency on bargaining behaviour, Journal of Personality and Social Psychology $30(3), 323-335$.

Zhang, Charles, and Norbert Schwarz, 2012, How and why 1 year differs from 365 days: A conversational logic analysis of inferences from the granularity of quantitative expressions, Journal of Consumer Research 39(2), 248-259.

Zhang, Charles, and Norbert Schwarz, 2013, The power of precise numbers: A conversational logic analysis, Journal of Experimental Social Psychology 49(5), 944-946.

Zhang, Yizi, 2013, The granularity effects: Numerical judgment from a social perspective, $\mathrm{PhD}$ dissertation, University of Michigan. 


\section{Figure 1}

Initial bid price frequency at various decimal and digit levels

Panel A reports the distribution of decimals in the initial bid price per share. Panel B reports the distribution of the last digit when the bid price is divisible by one dollar. All initial bids are cash-only bids for listed companies for at least five dollars per share, made between 1985 and 2012.

Panel A: Distribution of decimals, full sample

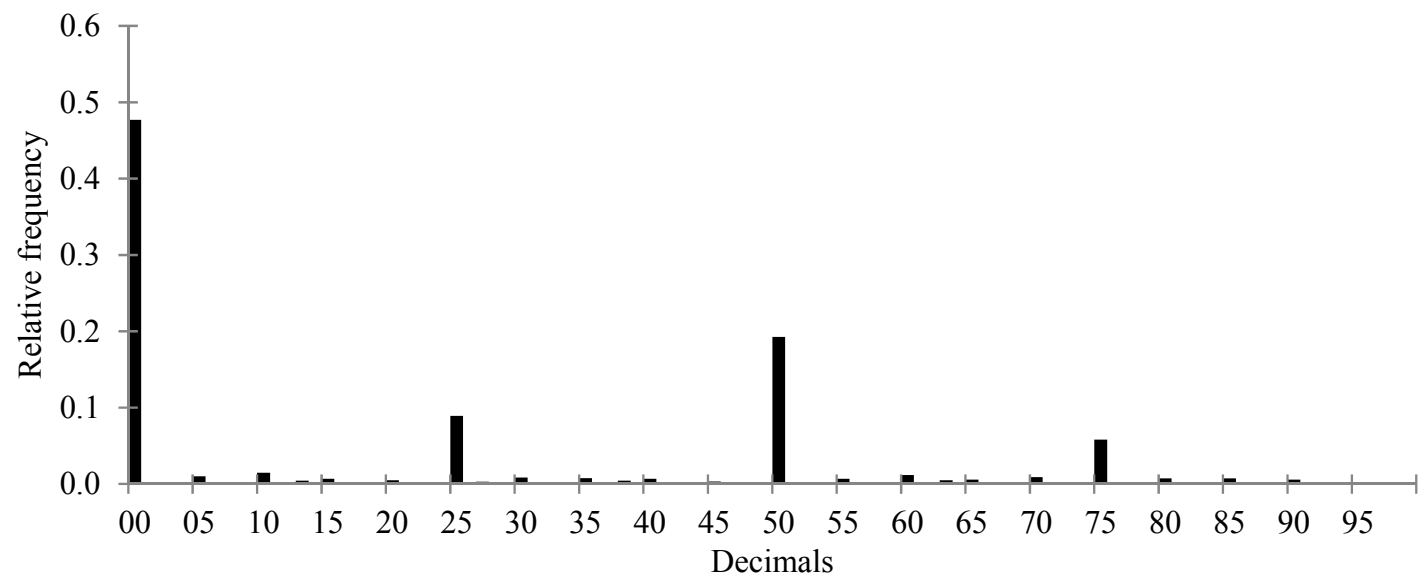

Panel B: Distribution of the last digit, conditional on the price per share being divisible by one dollar

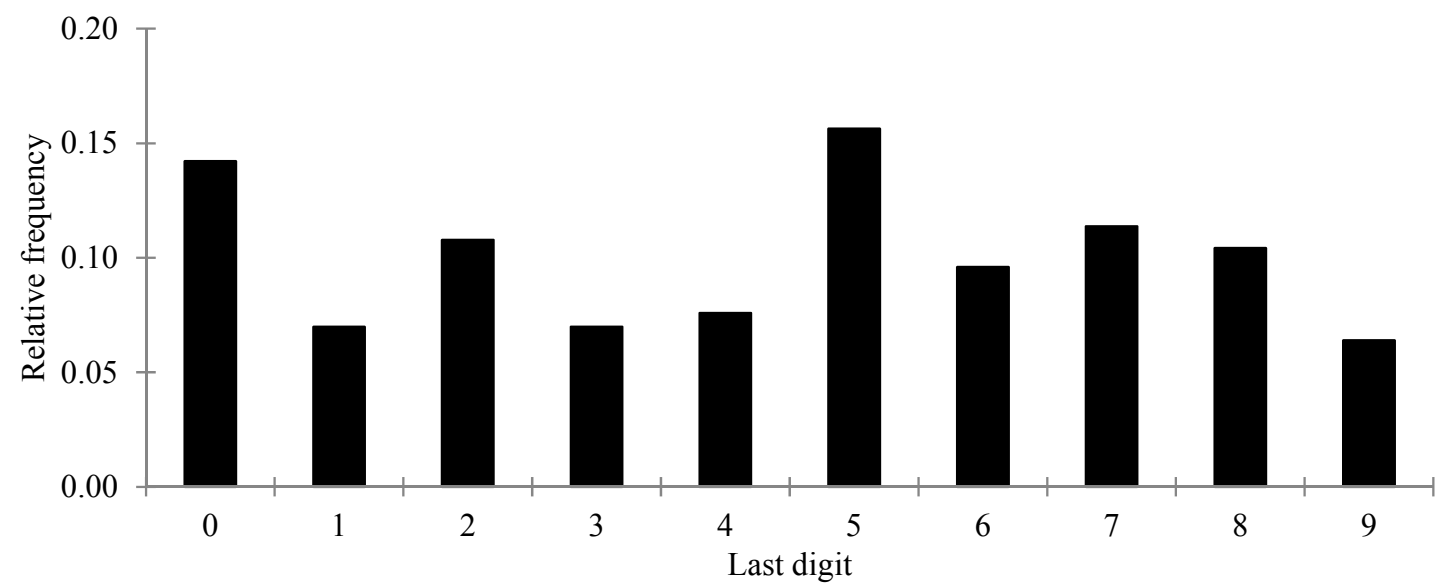




\section{Table 1 \\ Summary statistics}

Panel A reports means, standard deviations, and extreme values for the initial bid precision dummy variables. Five dollars takes the value of one if the bid price is divisible with five dollars. Dollar equals one if the bid price is divisible with one dollar but not with five dollars. Half dollar equals one if the bid price is divisible with fifty cents but not with a dollar. Quarter equals one if the bid price is divisible with 25 cents but not with 50 cents. Panel B reports takeover contest outcomes. Initial bidder wins equals one if one of the initial bidder's offers is completed. Competed equals one if the initial bid is challenged by some other control bidder. Contest duration is the number of calendar days from the initial offer announcement to completion of a deal or censored at 365 days. Relative price change is the relative change from the initial bid price per share to the final price per share of a completed offer. Price change dummy equals one if the price change differs from zero. Acquirer announcement return and Target announcement return are cumulative abnormal returns computed over trading days $[-1,+1]$ surrounding the initial bid. Panel $\mathrm{C}$ reports control variables. Tender offer equals one if the offer is classified as a tender offer by SDC. Hostile offer refers to an unsolicited offer or hostile target management reaction in the SDC data. Offer price is the offer price per share in the initial offer. Horizontal offer equals one if the target and the bidder are in the same 3-digit SIC code industry. Premium is the relative difference in the price per share offered and the target share price 30 days prior to the offer announcement. Transaction value is the value offered for the target shares based on the offer price per share in the initial offer in millions. Public acquirer equals one if the acquirer is listed on an exchange. Toehold is the bidder's ownership in the target at the time of the announcement. Volatility is the target's daily stock return standard deviation, calculated over event days $[-239,-20]$. Relative size is the ratio of the transaction value and acquirer equity market value. All initial bids are cash-only bids for listed companies for at least five dollars per share, made between 1985 and 2012.

\begin{tabular}{|c|c|c|c|c|c|c|c|c|}
\hline & $N$ & Avg & Std dev & Min & $25 \%$ & Median & $75 \%$ & $\operatorname{Max}$ \\
\hline \multicolumn{9}{|l|}{ Panel A } \\
\hline Five dollars & 1769 & 0.14 & 0.35 & 0 & 0 & 0 & 0 & 1 \\
\hline Dollar & 1769 & 0.33 & 0.47 & 0 & 0 & 0 & 1 & 1 \\
\hline Half dollar & 1769 & 0.19 & 0.39 & 0 & 0 & 0 & 0 & 1 \\
\hline Quarter & 1769 & 0.15 & 0.35 & 0 & 0 & 0 & 0 & 1 \\
\hline \multicolumn{9}{|l|}{ Panel B } \\
\hline Initial bidder wins & 1769 & 0.76 & 0.43 & 0 & 1 & 1 & 1 & 1 \\
\hline Competed & 1769 & 0.10 & 0.30 & 0 & 0 & 0 & 0 & 1 \\
\hline Contest duration & 1769 & 119 & 71 & 23 & 67 & 113 & 138 & 365 \\
\hline Relative price change & 260 & 0.14 & 0.18 & -0.61 & 0.04 & 0.12 & 0.22 & 0.92 \\
\hline Price change dummy & 1408 & 0.18 & 0.39 & 0 & 0 & 0 & 0 & 1 \\
\hline Acquirer announcement return & 308 & 0.013 & 0.07 & -0.24 & -0.02 & 0.01 & 0.05 & 0.38 \\
\hline Target announcement return & 1641 & 0.27 & 0.27 & -0.28 & 0.10 & 0.22 & 0.36 & 2.83 \\
\hline \multicolumn{9}{|l|}{ Panel C } \\
\hline Tender offer & 1769 & 0.30 & 0.46 & 0 & 0 & 0 & 1 & 1 \\
\hline Hostile offer & 1769 & 0.18 & 0.38 & 0 & 0 & 0 & 0 & 1 \\
\hline Offer price & 1769 & 23.66 & 19.97 & 5.00 & 10.50 & 18.25 & 29.50 & 240.00 \\
\hline Horizontal offer & 1769 & 0.32 & 0.47 & 0 & 0 & 0 & 1 & 1 \\
\hline Premium & 1769 & 0.42 & 0.86 & -0.57 & 0.18 & 0.32 & 0.51 & 28.55 \\
\hline Transaction value & 1769 & 986 & 2500 & 2 & 96 & 254 & 797 & 41000 \\
\hline Public acquirer & 1769 & 0.44 & 0.50 & 0 & 0 & 0 & 1 & 1 \\
\hline Toehold & 1769 & 2.27 & 7.37 & 0.00 & 0.00 & 0.00 & 0.00 & 49.90 \\
\hline Volatility & 260 & 0.03 & 0.01 & 0.01 & 0.02 & 0.03 & 0.04 & 0.11 \\
\hline Relative size & 308 & 0.46 & 0.56 & 0.10 & 0.16 & 0.27 & 0.52 & 4.48 \\
\hline
\end{tabular}


Table 2

Initial bid precision and offer outcomes

Columns $1-5$ of this table report on offer outcomes along with the number of observations as a function of the precision of the initial bid. Column 6 reports the difference between the least and the most precise bids, and column 7 the test statistic associated with this difference. All variables are defined in Table 1. ***,**, and * denote statistical significance at the $1 \%, 5 \%$, and $10 \%$ levels, respectively. All initial bids are cash-only bids for listed companies for at least five dollars per share, made between 1985 and 2012.

\begin{tabular}{|c|c|c|c|c|c|c|c|}
\hline \multirow{3}{*}{ Decimal digits } & \multicolumn{4}{|l|}{ Round } & \multicolumn{3}{|l|}{ Precise } \\
\hline & Five dollars & Dollar & Half dollar & Quarter & Other I & Diff. (1)-(5) & $z-/ t$-value \\
\hline & $(1)$ & $(2)$ & (3) & (4) & $(5)$ & $(6)$ & (7) \\
\hline$N$ & 252 & 592 & 341 & 261 & 323 & & \\
\hline Initial bidder wins & $69.0 \%$ & $74.8 \%$ & $74.2 \%$ & $76.2 \%$ & $84.2 \%$ & $-15.2 \%$ & $-4.32 * * *$ \\
\hline Competed & $12.3 \%$ & $9.6 \%$ & $13.8 \%$ & $6.1 \%$ & $7.7 \%$ & $4.6 \%$ & $1.83^{*}$ \\
\hline Contest duration & 130 & 122 & 117 & 112 & 113 & 17 & $2.87^{* * *}$ \\
\hline$N$ & 40 & 101 & 52 & 23 & 44 & & \\
\hline Relative price change & $17.6 \%$ & $14.3 \%$ & $19.1 \%$ & $8.3 \%$ & $6.0 \%$ & $11.6 \%$ & $3.43 * * *$ \\
\hline$N$ & 186 & 470 & 269 & 205 & 278 & & \\
\hline Price change dummy & $21.5 \%$ & $21.5 \%$ & $19.3 \%$ & $11.2 \%$ & $15.8 \%$ & $5.7 \%$ & 1.56 \\
\hline$N$ & 54 & 105 & 63 & 36 & 50 & & \\
\hline Acquirer announcement return & $0.1 \%$ & $0.2 \%$ & $2.3 \%$ & $2.9 \%$ & $2.3 \%$ & $-2.3 \%$ & $-1.91 *$ \\
\hline$N$ & 237 & 550 & 313 & 243 & 298 & & \\
\hline Target announcement return & $27.8 \%$ & $27.9 \%$ & $25.8 \%$ & $27.8 \%$ & $24.1 \%$ & $3.8 \%$ & 1.58 \\
\hline
\end{tabular}


Table 3

Initial bid precision and completing a deal

This table reports results from logit regressions which explain the likelihood that one of the initial bidder's bids is completed, with variables measuring initial bid precision and controls. All variables are defined in Table 1, except that Inverse price is the inverse of the offer price per share. $t$-values based on robust standard errors are reported in parentheses. Marginal effects evaluated at variable means are reported in brackets; dummy variables are evaluated at zero. $* * *, * *$, and $*$ denote statistical significance at the $1 \%, 5 \%$, and $10 \%$ levels, respectively. All initial bids are cash-only bids for listed companies for at least five dollars per share, made between 1985 and 2012.

\begin{tabular}{|c|c|c|c|}
\hline \multirow[t]{2}{*}{ Dependent variable } & \multicolumn{3}{|c|}{ Initial bidder completes a deal } \\
\hline & $(1)$ & $(2)$ & (3) \\
\hline Five dollars & $\begin{array}{l}-0.872 * * * \\
(-4.26) \\
{[-0.116]}\end{array}$ & & $\begin{array}{l}-0.661 * * * \\
(-2.60) \\
{[-0.079]}\end{array}$ \\
\hline Dollar & $\begin{array}{l}-0.584 * * * \\
(-3.25) \\
{[-0.078]}\end{array}$ & & $\begin{array}{l}-0.477 * * \\
(-2.01) \\
{[-0.057]}\end{array}$ \\
\hline Half dollar & $\begin{array}{l}-0.618 * * * \\
(-3.14) \\
{[-0.082]}\end{array}$ & & $\begin{array}{l}-0.533 * * \\
(-2.11) \\
{[-0.064]}\end{array}$ \\
\hline Quarter & $\begin{array}{l}-0.508 * * \\
(-2.41) \\
{[-0.068]}\end{array}$ & & $\begin{array}{l}-0.639^{* *} \\
(-2.45) \\
{[-0.076]}\end{array}$ \\
\hline Tender offer & & $\begin{array}{l}1.369 * * * \\
(7.08) \\
{[0.220]}\end{array}$ & $\begin{array}{l}1.408 * * * \\
(7.29) \\
{[0.168]}\end{array}$ \\
\hline Hostile offer & & $\begin{array}{c}-3.432 * * * \\
(-18.47) \\
{[-0.552]}\end{array}$ & $\begin{array}{c}-3.397 * * * \\
(-18.12) \\
{[-0.405]}\end{array}$ \\
\hline Inverse price & & $\begin{array}{l}-3.693 * * \\
(-2.15) \\
{[-0.594]}\end{array}$ & $\begin{array}{l}-4.217^{* *} \\
(-2.39) \\
{[-0.503]}\end{array}$ \\
\hline Horizontal offer & & $\begin{array}{l}0.293^{*} \\
(1.84) \\
{[0.047]}\end{array}$ & $\begin{array}{l}0.280^{*} \\
(1.74) \\
{[0.033]}\end{array}$ \\
\hline Premium & & $\begin{array}{l}0.000 \\
(0.00) \\
{[0.000]}\end{array}$ & $\begin{array}{l}0.009 \\
(0.20) \\
{[0.001]}\end{array}$ \\
\hline Ln (Transaction value) & & $\begin{array}{l}0.116^{* *} \\
(2.05) \\
{[0.019]}\end{array}$ & $\begin{array}{l}0.123 * * \\
(2.13) \\
{[0.015]}\end{array}$ \\
\hline Public acquirer & & $\begin{array}{l}0.516^{* * *} \\
(3.53) \\
{[0.083]}\end{array}$ & $\begin{array}{l}0.514^{* * *} \\
(3.50) \\
{[0.061]}\end{array}$ \\
\hline Toehold & & $\begin{array}{l}-0.010 \\
(-0.93) \\
{[-0.002]}\end{array}$ & $\begin{array}{l}-0.009 \\
(-0.83) \\
{[-0.001]}\end{array}$ \\
\hline Constant & $\begin{array}{l}1.674^{* * *} \\
(10.97)\end{array}$ & $\begin{array}{l}1.004 * * \\
(2.43)\end{array}$ & $\begin{array}{l}1.448^{* * *} \\
(3.11)\end{array}$ \\
\hline $\bar{N}$ & 1769 & 1769 & 1769 \\
\hline Pseudo $R^{2}$ & 0.010 & 0.313 & 0.318 \\
\hline Wald- $\chi^{2}$ & $19.07 * * *$ & $360.35 * * *$ & $371.34 * * *$ \\
\hline Wald- $-\chi^{2}($ Five dollars $=\ldots=$ Quarter $=0)$ & $19.07 * * *$ & & $8.25^{*}$ \\
\hline
\end{tabular}


Table 4

Initial bid precision and relative offer price change

This table reports results from OLS regressions which explain the relative price change from initial bid to final price for a completed offer with variables measuring initial bid precision and controls. All variables are defined in Table 1, except that Inverse price is the inverse of the offer price per share. $t$-values based on robust standard errors are reported in parentheses. $* * *, * *$, and $*$ denote the statistical significance at the $1 \%, 5 \%$, and $10 \%$ levels, respectively. All initial bids are cash-only bids for listed companies for at least five dollars per share, made between 1985 and 2012 .

\begin{tabular}{|c|c|c|c|}
\hline \multirow[t]{2}{*}{ Dependent variable } & \multicolumn{3}{|c|}{ Relative offer price change } \\
\hline & $(1)$ & $(2)$ & (3) \\
\hline Five dollars & $\begin{array}{l}0.116^{* * *} \\
(3.40)\end{array}$ & & $\begin{array}{l}0.101 * * * \\
(2.88)\end{array}$ \\
\hline Dollar & $\begin{array}{l}0.083^{* * * *} \\
(3.17)\end{array}$ & & $\begin{array}{l}0.076^{* * *} \\
(2.74)\end{array}$ \\
\hline Half dollar & $\begin{array}{l}0.132 * * * \\
(3.73)\end{array}$ & & $\begin{array}{l}0.124 * * * \\
(3.71)\end{array}$ \\
\hline Quarter & $\begin{array}{c}0.024 \\
(0.46)\end{array}$ & & $\begin{array}{c}0.002 \\
(0.04)\end{array}$ \\
\hline Tender offer & & $\begin{array}{c}0.030 \\
(1.15)\end{array}$ & $\begin{array}{r}0.025 \\
(0.98)\end{array}$ \\
\hline Hostile offer & & $\begin{array}{l}0.085^{* * * *} \\
(3.37)\end{array}$ & $\begin{array}{l}0.075^{* * *} \\
(3.14)\end{array}$ \\
\hline Inverse price & & $\begin{array}{r}0.593 \\
(1.53)\end{array}$ & $\begin{array}{l}0.741^{* *} \\
(2.00)\end{array}$ \\
\hline Horizontal offer & & $\begin{array}{l}0.020 \\
(0.72)\end{array}$ & $\begin{array}{r}0.021 \\
(0.73)\end{array}$ \\
\hline Premium & & $\begin{array}{c}0.018 \\
(0.52)\end{array}$ & $\begin{array}{r}0.012 \\
(0.38)\end{array}$ \\
\hline Ln (Transaction value) & & $\begin{array}{l}0.006 \\
(0.65)\end{array}$ & $\begin{array}{r}0.007 \\
(0.71)\end{array}$ \\
\hline Public acquirer & & $\begin{array}{r}0.002 \\
(0.09)\end{array}$ & $\begin{array}{r}0.002 \\
(0.08)\end{array}$ \\
\hline Toehold & & $\begin{array}{r}0.000 \\
(0.14)\end{array}$ & $\begin{array}{l}-0.000 \\
(-0.57)\end{array}$ \\
\hline Volatility & & $\begin{array}{c}0.304 \\
(0.22)\end{array}$ & $\begin{array}{c}0.310 \\
(0.24)\end{array}$ \\
\hline Constant & $\begin{array}{l}0.060^{* * *} \\
(2.93)\end{array}$ & $\begin{array}{r}-0.007 \\
(-0.09) \\
\end{array}$ & $\begin{array}{c}-0.078 \\
(-0.95) \\
\end{array}$ \\
\hline $\bar{N}$ & 260 & 260 & 260 \\
\hline$R^{2}$ & 0.064 & 0.091 & 0.147 \\
\hline$F$-statistic & $5.20 * * *$ & $3.00 * * *$ & $3.38 * * *$ \\
\hline$F$-statistic $($ Five dollars $=\ldots=$ Quarter $=0)$ & $5.20 * * *$ & & $4.22 * *$ \\
\hline
\end{tabular}


Table 5

Initial bid precision and the acquirer's stock market reaction

This table reports results from OLS regressions which explain the acquirer's cumulative abnormal return computed over trading days $[-1,+1]$ surrounding the initial bid, with variables measuring initial bid precision and controls. All variables are defined in Table 1, except that Inverse price is the inverse of the offer price per share. $t$-values based on robust standard errors are reported in parentheses. $* * *, * *$, and $*$ denote statistical significance at the $1 \%, 5 \%$, and $10 \%$ levels, respectively. All initial bids are cash-only bids for listed companies for at least five dollars per share, made between 1985 and 2012.

\begin{tabular}{|c|c|c|c|}
\hline \multirow[t]{2}{*}{ Dependent variable } & \multicolumn{3}{|c|}{ Acquirer cumulative abnormal return $[-1,+1]$} \\
\hline & (1) & (2) & (3) \\
\hline Five dollars & $\begin{array}{l}-0.023^{*} \\
(-1.92)\end{array}$ & & $\begin{array}{l}-0.020^{*} \\
(-1.68)\end{array}$ \\
\hline Dollar & $\begin{array}{l}-0.022^{* *} \\
(-2.12)\end{array}$ & & $\begin{array}{l}-0.020^{*} \\
(-1.90)\end{array}$ \\
\hline Half dollar & $\begin{array}{l}-0.000 \\
(-0.01)\end{array}$ & & $\begin{array}{l}-0.003 \\
(-0.22)\end{array}$ \\
\hline Quarter & $\begin{array}{c}0.005 \\
(0.30)\end{array}$ & & $\begin{array}{r}0.000 \\
(0.00)\end{array}$ \\
\hline Tender offer & & $\begin{array}{l}0.015^{*} \\
(1.80)\end{array}$ & $\begin{array}{l}0.013^{*} \\
(1.66)\end{array}$ \\
\hline Hostile offer & & $\begin{array}{l}-0.027 * * * \\
(-3.06)\end{array}$ & $\begin{array}{l}-0.024^{* * *} \\
(-2.68)\end{array}$ \\
\hline Inverse price & & $\begin{array}{l}-0.080 \\
(-0.90)\end{array}$ & $\begin{array}{l}-0.105 \\
(-1.19)\end{array}$ \\
\hline Horizontal offer & & $\begin{array}{l}-0.007 \\
(-0.86)\end{array}$ & $\begin{array}{l}-0.006 \\
(-0.72)\end{array}$ \\
\hline Premium & & $\begin{array}{l}-0.005 \\
(-0.42)\end{array}$ & $\begin{array}{l}-0.003 \\
(-0.20)\end{array}$ \\
\hline Ln (Transaction value) & & $\begin{array}{l}-0.008^{* * *} \\
(-2.85)\end{array}$ & $\begin{array}{l}-0.008^{* * *} \\
(-2.83)\end{array}$ \\
\hline Ln (Relative size) & & $\begin{array}{l}0.017 * * \\
(2.58)\end{array}$ & $\begin{array}{l}0.016^{* * *} \\
(2.60)\end{array}$ \\
\hline Constant & $\begin{array}{l}0.023 * * * \\
(2.88)\end{array}$ & $\begin{array}{l}0.091 * * * \\
(3.92)\end{array}$ & $\begin{array}{l}0.101^{* * *} \\
(4.33)\end{array}$ \\
\hline $\bar{N}$ & 308 & 308 & 308 \\
\hline$R^{2}$ & 0.029 & 0.085 & 0.104 \\
\hline$F$-statistic & $2.31 *$ & $3.26 * * *$ & $2.77 * * *$ \\
\hline$F$-statistic $($ Five dollars $=\ldots=$ Quarter $=0)$ & $2.31 *$ & & 1.61 \\
\hline
\end{tabular}


Table 6

Semi-structured interviews of ten senior M\&A professionals

This table reports results from semi-structured interviews with ten senior M\&A professionals. All interviews were conducted by the same person, three face-to-face and seven via phone or skype. Panel A reports descriptive statistics on the professional background of the interviewees. Panel B reports descriptive statistics on the length of their work experience and the interview. Panel $\mathrm{C}$ reports the distribution of the interviewees' preference for round vs. precise offers. Panel D reports descriptive statistics on the other results of the interview.

Panel A: Descriptive statistics on the professional background of the interviewees

\begin{tabular}{lc}
\hline & \# interviewees \\
\hline Experience from investment banking & 10 \\
Works in a bulge-bracket bank & 4 \\
Has worked in a bulge-bracket bank & 2 \\
Experience from corporate M\&A & 2 \\
Experience from private equity & 1 \\
Total number of interviewees & 10 \\
\hline
\end{tabular}

Panel B: Descriptive statistics on the length of the interviews and interviewees' work experience

\begin{tabular}{lccccc}
\hline & Mean & Median & Std. dev. & Min & Max \\
\hline Experience length, years & 14 & 13 & 4 & 8 & 21 \\
Interview length, minutes & 23 & 20 & 5 & 15 & 35 \\
\hline
\end{tabular}

Panel C: Distribution of the interviewees' preference for round vs. precise offers

\begin{tabular}{|c|c|c|c|c|c|}
\hline & \multicolumn{5}{|c|}{ Preference for } \\
\hline & \multicolumn{2}{|c|}{ Round offers } & \multirow{2}{*}{$\begin{array}{l}\text { Neither round } \\
\text { nor precise }\end{array}$} & \multicolumn{2}{|c|}{ Precise offers } \\
\hline & Strong & Weak & & Weak & Strong \\
\hline \# interviewees & 2 & 3 & 2 & 2 & 1 \\
\hline
\end{tabular}

Panel D: Descriptive statistics on other interview results

\begin{tabular}{lc}
\hline & \# interviewees \\
\hline Has discussed rounding with colleagues & 3 \\
Is aware of research on bid precision & 0 \\
\hline
\end{tabular}


Table IA1

Initial bid precision and the target's stock market reaction

This table reports results from an OLS regression which explains the target's cumulative abnormal return computed over trading days $[-1,+1]$ surrounding the initial bid, with variables measuring initial bid precision and controls. All variables are defined in Table 1, except that Inverse price is the inverse of the offer price per share. $t$-values based on robust standard errors are reported in parentheses. $* * *, * *$, and $*$ denote statistical significance at the $1 \%, 5 \%$, and $10 \%$ levels, respectively. All initial bids are cash-only bids for listed companies for at least five dollars per share, made between 1985 and 2012.

\begin{tabular}{|c|c|c|c|}
\hline \multirow[t]{2}{*}{ Dependent variable } & \multicolumn{3}{|c|}{ Target cumulative abnormal return $[-1,+1]$} \\
\hline & $(1)$ & (2) & (3) \\
\hline \multirow[t]{2}{*}{ Five dollars } & 0.038 & & 0.015 \\
\hline & $(1.59)$ & & $(0.52)$ \\
\hline \multirow[t]{2}{*}{ Dollar } & $0.038^{*}$ & & 0.031 \\
\hline & $(1.93)$ & & $(1.24)$ \\
\hline \multirow[t]{2}{*}{ Half dollar } & 0.017 & & 0.022 \\
\hline & $(0.81)$ & & $(1.05)$ \\
\hline \multirow[t]{2}{*}{ Quarter } & 0.037 & & 0.022 \\
\hline & $(1.55)$ & & $(0.94)$ \\
\hline \multirow[t]{2}{*}{ Tender offer } & & $0.058 * * *$ & $0.056 * * *$ \\
\hline & & $(3.20)$ & $(3.23)$ \\
\hline \multirow[t]{2}{*}{ Hostile offer } & & $-0.040 * * *$ & $-0.043^{* * *}$ \\
\hline & & $(-3.11)$ & $(-2.91)$ \\
\hline \multirow[t]{2}{*}{ Inverse price } & & 0.201 & 0.244 \\
\hline & & $(1.16)$ & $(1.25)$ \\
\hline \multirow[t]{2}{*}{ Horizontal offer } & & $0.042 * * *$ & $0.042 * * *$ \\
\hline & & $(3.45)$ & $(3.45)$ \\
\hline \multirow[t]{2}{*}{ Premium } & & $0.347 * * *$ & $0.346 * * *$ \\
\hline & & $(3.51)$ & $(3.47)$ \\
\hline \multirow[t]{2}{*}{ Ln (Transaction value) } & & $0.009 * *$ & $0.009 * *$ \\
\hline & & $(2.48)$ & $(2.39)$ \\
\hline \multirow[t]{2}{*}{ Constant } & $0.241 * * *$ & 0.040 & 0.019 \\
\hline & $(15.14)$ & $(0.95)$ & $(0.51)$ \\
\hline$N$ & 1641 & 1641 & 1641 \\
\hline$R^{2}$ & 0.003 & 0.374 & 0.375 \\
\hline$F$-statistic & 1.26 & $21.50 * * *$ & $15.45 * * *$ \\
\hline$F$-statistic $($ Five dollars $=\ldots=$ Quarter $=0)$ & 1.26 & & 0.68 \\
\hline
\end{tabular}


Table IA2

Initial bid precision and the likelihood of competing offers

This table reports results from a logit regression which explains the likelihood that the initial bid is challenged by some other control bidder, with variables measuring initial bid precision and controls. All variables are defined in Table 1, except that Inverse price is the inverse of the offer price per share. $t$-values based on robust standard errors are reported in parentheses. $* * *, * *$, and * denote statistical significance at the $1 \%, 5 \%$, and $10 \%$ levels, respectively. All initial bids are cash-only bids for listed companies for at least five dollars per share, made between 1985 and 2012.

\begin{tabular}{|c|c|c|c|}
\hline \multirow[t]{2}{*}{ Dependent variable } & \multicolumn{3}{|c|}{ Likelihood of competing offers } \\
\hline & (1) & $(2)$ & (3) \\
\hline Five dollars & $\begin{array}{l}0.514^{*} \\
(1.82) \\
{[0.037]}\end{array}$ & & $\begin{array}{l}0.101 \\
(0.33) \\
{[0.006]}\end{array}$ \\
\hline Dollar & $\begin{array}{l}0.239 \\
(0.95) \\
{[0.017]}\end{array}$ & & $\begin{array}{l}-0.054 \\
(-0.20) \\
{[-0.003]}\end{array}$ \\
\hline Half dollar & $\begin{array}{l}0.645^{* *} \\
(2.47) \\
{[0.046]}\end{array}$ & & $\begin{array}{l}0.386 \\
(1.39) \\
{[0.023]}\end{array}$ \\
\hline Quarter & $\begin{array}{l}-0.250 \\
(-0.76) \\
{[-0.018]}\end{array}$ & & $\begin{array}{l}-0.367 \\
(-1.05) \\
{[-0.022]}\end{array}$ \\
\hline Tender offer & & $\begin{array}{l}-0.133 \\
(-0.74) \\
{[-0.008]}\end{array}$ & $\begin{array}{l}-0.139 \\
(-0.78) \\
{[-0.008]}\end{array}$ \\
\hline Hostile offer & & $\begin{array}{c}1.850 * * * \\
(10.85) \\
{[0.113]}\end{array}$ & $\begin{array}{l}1.832 * * * \\
(10.60) \\
{[0.110]}\end{array}$ \\
\hline Inverse price & & $\begin{array}{l}1.302 \\
(0.63) \\
{[0.080]}\end{array}$ & $\begin{array}{l}1.478 \\
(0.70) \\
{[0.088]}\end{array}$ \\
\hline Horizontal offer & & $\begin{array}{l}-0.213 \\
(-1.09) \\
{[-0.013]}\end{array}$ & $\begin{array}{l}-0.205 \\
(-1.04) \\
{[-0.012]}\end{array}$ \\
\hline Premium & & $\begin{array}{l}0.101^{* *} \\
(2.52) \\
{[0.006]}\end{array}$ & $\begin{array}{l}0.092 * * \\
(2.23) \\
{[0.005]}\end{array}$ \\
\hline Ln (Transaction value) & & $\begin{array}{l}-0.010 \\
(-0.15) \\
{[-0.001]}\end{array}$ & $\begin{array}{l}-0.012 \\
(-0.18) \\
{[-0.001]}\end{array}$ \\
\hline Public acquirer & & $\begin{array}{l}-0.071 \\
(-0.41) \\
{[-0.004]}\end{array}$ & $\begin{array}{l}-0.082 \\
(-0.47) \\
{[-0.005]}\end{array}$ \\
\hline Toehold & & $\begin{array}{l}0.010 \\
(1.07) \\
{[0.001]}\end{array}$ & $\begin{array}{l}0.008 \\
(0.89) \\
{[0.000]}\end{array}$ \\
\hline Constant & $\begin{array}{l}-2.478 * * * \\
(-11.90)\end{array}$ & $\begin{array}{l}-2.758 * * * \\
(-5.72)\end{array}$ & $\begin{array}{l}-2.778 * * * \\
(-5.31)\end{array}$ \\
\hline $\bar{N}$ & 1769 & 1769 & 1769 \\
\hline Pseudo $R^{2}$ & 0.012 & 0.112 & 0.119 \\
\hline Wald- $\chi^{2}$ & $12.86 * *$ & $155.70 * * *$ & $160.01 * * *$ \\
\hline Wald- $\chi^{2}($ Five dollars $=\ldots=$ Quarter $=0)$ & $12.86^{* *}$ & & 7.22 \\
\hline
\end{tabular}


Table IA3

Initial bid precision and the likelihood of price change

This table reports results from a logit regression which explains the likelihood that the final price of a completed offer differs from the initial bid, with variables measuring initial bid precision and controls. All variables are defined in Table 1, except that Inverse price is the inverse of the offer price per share. $t$-values based on robust standard errors are reported in parentheses. Marginal effects evaluated at variable means are reported in brackets; dummy variables are evaluated at zero. $* * *, * *$, and * denote statistical significance at the $1 \%, 5 \%$, and $10 \%$ levels, respectively. All initial bids are cash-only bids for listed companies for at least five dollars per share, made between 1985 and 2012 . 


\begin{tabular}{|c|c|c|c|}
\hline \multirow[t]{2}{*}{ Dependent variable } & \multicolumn{3}{|c|}{ Likelihood of price change } \\
\hline & (1) & (2) & (3) \\
\hline Five dollars & $\begin{array}{l}0.376 \\
(1.55) \\
{[0.050]}\end{array}$ & & $\begin{array}{l}0.037 \\
(0.11) \\
{[0.005]}\end{array}$ \\
\hline Dollar & $\begin{array}{l}0.375^{*} \\
(1.89) \\
{[0.050]}\end{array}$ & & $\begin{array}{l}0.197 \\
(0.75) \\
{[0.027]}\end{array}$ \\
\hline Half dollar & $\begin{array}{l}0.242 \\
(1.08) \\
{[0.032]}\end{array}$ & & $\begin{array}{l}0.066 \\
(0.22) \\
{[0.009]}\end{array}$ \\
\hline Quarter & $\begin{array}{l}-0.397 \\
(-1.44) \\
{[-0.053]}\end{array}$ & & $\begin{array}{l}-0.530 \\
(-1.54) \\
{[-0.074]}\end{array}$ \\
\hline Tender offer & & $\begin{array}{l}-0.543 * * \\
(-2.49) \\
{[-0.076]}\end{array}$ & $\begin{array}{l}-0.544^{* *} \\
(-2.49) \\
{[-0.076]}\end{array}$ \\
\hline Hostile offer & & $\begin{array}{l}4.555^{* * *} \\
(12.13) \\
{[0.638]}\end{array}$ & $\begin{array}{c}4.542 * * * \\
(11.95) \\
{[0.633]}\end{array}$ \\
\hline Inverse price & & $\begin{array}{l}0.478 \\
(0.19) \\
{[0.067]}\end{array}$ & $\begin{array}{l}0.891 \\
(0.35) \\
{[0.124]}\end{array}$ \\
\hline Horizontal offer & & $\begin{array}{l}-0.408^{* *} \\
(-2.03) \\
{[-0.057]}\end{array}$ & $\begin{array}{l}-0.414^{* *} \\
(-2.05) \\
{[-0.058]}\end{array}$ \\
\hline Premium & & $\begin{array}{l}-0.178 \\
(-0.83) \\
{[-0.025]}\end{array}$ & $\begin{array}{l}-0.197 \\
(-0.89) \\
{[-0.027]}\end{array}$ \\
\hline Ln (Transaction value) & & $\begin{array}{l}-0.027 \\
(-0.38) \\
{[-0.004]}\end{array}$ & $\begin{array}{l}-0.033 \\
(-0.45) \\
{[-0.005]}\end{array}$ \\
\hline Public acquirer & & $\begin{array}{l}-0.611 * * * \\
(-3.25) \\
{[-0.086]}\end{array}$ & $\begin{array}{l}-0.633^{* * *} \\
(-3.33) \\
{[-0.088]}\end{array}$ \\
\hline Toehold & & $\begin{array}{l}0.068^{* * *} \\
(6.37) \\
{[0.010]}\end{array}$ & $\begin{array}{l}0.068^{* * *} \\
(6.36) \\
{[0.009]}\end{array}$ \\
\hline Volatility & & $\begin{array}{l}7.203 \\
(1.21) \\
{[1.009]}\end{array}$ & $\begin{array}{l}7.053 \\
(1.14) \\
{[0.982]}\end{array}$ \\
\hline Constant & $\begin{array}{l}-1.671^{* * *} \\
(-10.17)\end{array}$ & $\begin{array}{l}-1.739^{* * *} \\
(-3.14)\end{array}$ & $\begin{array}{l}-1.726^{* * *} \\
(-2.91)\end{array}$ \\
\hline$N$ & 1408 & 1408 & 1408 \\
\hline $\begin{array}{l}\text { Pseudo } R^{2} \\
\text { Wald- } \chi^{2}\end{array}$ & $\begin{array}{c}0.010 \\
12.24 * *\end{array}$ & $\begin{array}{c}0.326 \\
181.75^{* * *}\end{array}$ & $\begin{array}{c}0.331 \\
180.58 * * *\end{array}$ \\
\hline Wald- $\chi^{2}($ Five dollars $=\ldots=$ Quarter $=0)$ & $12.24 * *$ & & 5.66 \\
\hline
\end{tabular}


Table IA4

Initial bid precision and contest duration

This table reports results from Cox proportional hazards model regressions which explain the duration from initial offer announcement to completion of the offer with variables measuring initial bid precision and controls. A negative coefficient value indicates a lower hazard and thereby longer duration. All variables are defined in Table 1, except that Inverse price is the inverse of the offer price per share. $t$-values based on robust standard errors are reported in parentheses. $* * *, * *$, and $*$ denote the statistical significance at the $1 \%, 5 \%$, and $10 \%$ levels, respectively. All initial bids are cash-only bids for listed companies for at least five dollars per share, made between 1985 and 2012 .

\begin{tabular}{|c|c|c|c|}
\hline \multirow[t]{2}{*}{ Dependent variable } & \multicolumn{3}{|c|}{ Contest duration } \\
\hline & $(1)$ & $(2)$ & (3) \\
\hline Five dollars & $\begin{array}{l}-0.351 * * * \\
(-3.76)\end{array}$ & & $\begin{array}{l}-0.200^{*} \\
(-1.87)\end{array}$ \\
\hline Dollar & $\begin{array}{l}-0.189^{* *} \\
(-2.38)\end{array}$ & & $\begin{array}{l}-0.074 \\
(-0.78)\end{array}$ \\
\hline Half dollar & $\begin{array}{l}-0.122 \\
(-1.41)\end{array}$ & & $\begin{array}{l}-0.142 \\
(-1.28)\end{array}$ \\
\hline Quarter & $\begin{array}{c}-0.054 \\
(-0.60)\end{array}$ & & $\begin{array}{l}-0.025 \\
(-0.25)\end{array}$ \\
\hline Tender offer & & $\begin{array}{l}1.206^{* * * *} \\
(14.99)\end{array}$ & $\begin{array}{l}1.209 * * * \\
(14.88)\end{array}$ \\
\hline Hostile offer & & $\begin{array}{l}-1.747 * * * \\
(-16.04)\end{array}$ & $\begin{array}{l}-1.738^{* * *} \\
(-15.84)\end{array}$ \\
\hline Inverse price & & $\begin{array}{c}0.868 \\
(1.11)\end{array}$ & $\begin{array}{r}0.715 \\
(0.91)\end{array}$ \\
\hline Horizontal offer & & $\begin{array}{c}0.013 \\
(0.19)\end{array}$ & $\begin{array}{r}0.009 \\
(0.14)\end{array}$ \\
\hline Premium & & $\begin{array}{l}-0.004 \\
(-0.15)\end{array}$ & $\begin{array}{r}0.001 \\
(0.02)\end{array}$ \\
\hline Ln (Transaction value) & & $\begin{array}{r}0.031 \\
(1.39)\end{array}$ & $\begin{array}{r}0.034 \\
(1.51)\end{array}$ \\
\hline Public acquirer & & $\begin{array}{l}0.220^{* * *} \\
(3.50)\end{array}$ & $\begin{array}{l}0.229^{* * *} \\
(3.68)\end{array}$ \\
\hline Toehold & & $\begin{array}{l}-0.023 * * * \\
(-5.39)\end{array}$ & $\begin{array}{l}-0.023 * * * \\
(-5.22)\end{array}$ \\
\hline$N$ & 1769 & 1769 & 1769 \\
\hline Number of failures & 1415 & 1415 & 1415 \\
\hline Wald- $\chi^{2}$ & $17.13 * * *$ & $404.39 * * *$ & $414.77 * * *$ \\
\hline Wald $-\chi^{2}($ Five dollars $=\ldots=$ Quarter $=0)$ & $17.13 * * *$ & & 4.98 \\
\hline
\end{tabular}

